\title{
FLAVONE CONTENT ANALYSIS OF WOGONIN (5,7- DIHYDROXY-8-METHOXY) FROM Tetracera indica L. MERR
}

\author{
R. Sukmawati ${ }^{1}$, D. Guntoro ${ }^{2, *}$, and A. Junaedi ${ }^{3}$ \\ ${ }^{1}$ Study Program of Agronomy and Horticulture, Graduate School, IPB University (Bogor \\ Agricultural University). Jl. Meranti, Kampus IPB Darmaga, Bogor 16680, Indonesia; \\ ${ }^{2,3}$ Department of Agronomy and Horticulture, Faculty of Agriculture, IPB University (Bogor \\ Agricultural University). Jl. Meranti, Kampus IPB Darmaga, Bogor 16680, Indonesia; \\ *E-mail: dwi_guntoro@ipb.ac.id
}

\begin{abstract}
One of the plants that contain flavonoid compounds is the Tetracera indica L. Merr plant which comes from the Dilleniaceae family and is known by the common name of site. Phytochemical tests on the part of the grading fruit indicate the presence of phenolic compounds, namely flavonoids, so it is necessary to isolate and identify the compounds contained in the grading fruit. Compounds 9, 12-Octadecadienoic acid (Z,Z), Flavone, 5,7-dihydroxy-8methoxy, and Hexadecanoic acid are three compounds with the largest content and are contained in all parts of Tetracera. indica. This experiment was conducted to determine the content and to analyze the content of flavone, 5,7 dihydroxy-8-Methoxy (wogonin) in the Tetracera indica L. Merr plant. This experiment was conducted in October 2018 to March 2019. Analysis of the wogonin compound was carried out using HPLC (Shimadzu LC20AD) equipped with a Luna C18 column. $5 \mu \mathrm{m}(150 \times 4.6 \mathrm{~mm}$, Phenomenex), with a wavelength of $270 \mathrm{~nm}$. Wogonin compounds were found in the Tetracera indica plant extract at a retention time of 18.053 minutes from the reference standard and extract using spike injection at a wavelength of $270 \mathrm{~nm}$ by the HPLC instrument in this study.

Keywords: Tetracera indica L Merr, Flavone, 5,7-Dihydroxy-8-methoxy(wogonin), High-performance Liquid Chromatography.
\end{abstract}

(c) RASĀYAN. All rights reserved

\section{INTRODUCTION}

One of the plants that contain flavonoid compounds is the Tetracera indica L. Merr plant, which comes from the Dilleniaceae family and is known by the common name of making Tetracera plant species thrive in the Asian forest region from Malaysia, Indonesia, Thailand, Vietnam, China to Guiana. With the diversity of its species, in general, the plant has the same uses and benefits, namely as an antiinflammatory, antioxidant and has a hepatoprotective activity; related to the chemical content contained in it. Previous research has shown that there is a class of flavonoid compounds, 5,7-dihydroxy-8-methoxy flavone which has been isolated from pathetic plants. Phytochemical tests on the phishing plant parts indicate the presence of phenolic compounds, namely flavonoids, so it is necessary to isolate and identify the compounds contained in the grading fruit ${ }^{1}$.

The results of the identification of the compound content of Tetracera indica according to research conducted $^{2}$. The results of the GC-MS analysis showed that there are various types of compounds scattered with different compositions and percentages in each part of the Tetracera indica. Compounds 9 , 12-Octadecadienoic acid (Z, Z), Flavone, 5,7-dihydroxy-8-methoxy, and Hexadecanoic acid are three compounds with the largest content and are contained in all parts of Tetracera indica. The compound with the highest percent area in all parts of Tetracera indica is 9, 12-Octadecadienoic acid $(\mathrm{Z}, \mathrm{Z})^{3}$. Flavonoids are known to have a role in inhibiting growth, which acts as a strong inhibitor of IAA-oxidase, but so far there has been no research on the wogonin activity as an allelochemical ${ }^{4}$. According to research wogonin compounds are known to have potential as a drug for diabetes mellitus ${ }^{4,5}$. This experiment was carried out to determine the content and to analyze the content of flavone, 5,7 dihydroxy-8-methoxy (wogonin) in plants Tetracera indica L. Merr. ${ }^{1-5}$

Rasayan J. Chem., 13(2), 1124-1128(2020)

http://dx.doi.org/10.31788/RJC.2020.1325522 
RASĀYAN J. Chem.

Vol. 13 | No. 2 |1124 - 1128| April - June | 2020

\section{EXPERIMENTAL}

\section{Material and Methods}

The production of Tetracera indica extract was carried out at the Ecotoxicology and Biogen Laboratory, Department of Agronomy and Horticulture, Faculty of Agriculture, IPB. The making of Tetracera indica and wogonin compound content analysis were carried out at the Biofarmaka Study Center Laboratory, LPPM IPB. The series of studies was carried out in October 2018.

The material needed in this study is Tertracera indica plant obtained from the Cikabayan Experimental Garden, Dramaga Campus of IPB (60 54 "1 LS, 106.713" BT). Paper Whatman no.1 (GE), wogonin reference standard (ALB Materials Inc.), pro-HPLC methanol (Merck), aquadest (Biopharmaca Lab. IPB), and 96\% ethanol (Brand). The tool used is High-Performance Liquid Chromatography (Shimadzu LC-20AD) equipped with a Luna C18 column. $5 \mu \mathrm{m}$ (150 x $4.6 \mathrm{~mm}$, Phenomenex).

\section{General Procedure}

\section{Intake of Plant Tetracera indica}

Tetracera indica plants were obtained directly from the Cikabayan IPB experimental garden, the leaves and stems were taken from attached trees because these plants spread to other plants and were attached. After it is cleaned and dried aerated. The leaves and stems of Tetracera indica are then cut into pieces to be mashed by grinding with a chopper machine in the Laboratory of Animal Husbandry Industry of IPB Campus.

\section{Manufacture of Tetracera indica Extract}

Tetracera indica was extracted by maceration method using methanol $96 \%$ for 24 hours. The suspension is taken and filtered. Immersion with $96 \%$ methanol was repeated three times. The results of the immersion are filtered using filter paper. The filtrate obtained was evaporated with a rotary evaporator at a temperature of $50-60{ }^{\circ} \mathrm{C}$ under vacum pressure to obtain a thick extract and all the solvents separated ${ }^{6}$. Analysis of Wogonin Compounds

Wogonin compound analysis is performed using analytical HPLC type HPLC is used to calculate and/or identify compounds.

The wogonin reference standard was diluted $50 \mu 1$ to $100 \mu 1$ with methanol with centrifuge results at 13,000 min from 5 minutes before being injected $10 \mu$ into HPLC (Shimadzu LC-20AD) equipped with Luna $\mathrm{C} 18$ column. $5 \mu \mathrm{m}(150 \times 4.6 \mathrm{~mm}$, Phenomenex), adjusted to the temperature in the elution gradient room, used 0.1 formid acid (elution A) and methanol (elution B). Conditions in the mobile phase of $45 \%$ of elution B with $60 \%$ similarity in conditions from 2-10 minutes are followed by a $70 \%$ mobile phase of elution B 30 minutes and up to $99 \%$ elution B to 31 minutes. The column will return to normal in the $33^{\text {rd }}$ to $35^{\text {th }}$ minutes. The flow rate of $\mathrm{mL} / \mathrm{min}$ with an injection volume of $10 \mu \mathrm{l}$ and detected with a wavelength of $270 \mathrm{~nm}^{7}$.

\section{Calculation of Compound Content of Analysis Results in Tetracera indica Extract}

The identification of compounds is done by observing the results of the chromatogram from the extract). Chromatogram results were observed for retention time, area and peak height of the graph. The content of wogonin is calculated based on the area shown in the analysis using the formula.

$$
\text { Content }(\%)=\frac{\text { Sample area }}{[\text { Sampels }]} \times \frac{[\text { Standard }]}{\text { Standard Area size }} \times 100 \%
$$

\section{RESULTS AND DISCUSSION}

Tetracera indica plants were extracted by maceration method using methanol as a solvent. Maceration was done by soaking the dry powder in the macerator. The process of immersion of the sample will cause the breakdown of cell walls and membranes due to the immersion of pressure between inside and outside the cell so that secondary metabolites that stand in the cytoplasm will be dissolved in the organic solvent used. Methanol is used as a maceration solvent because it can dissolve almost all organic compounds, both polar, semi-polar and non-polar. Besides, methanol has a fairly low boiling point $\left(64.5^{\circ} \mathrm{C}\right)$, making it 
RASĀYAN J. Chem.

Vol. 13 | No. 2 |1124 - 1128| April - June | 2020 easier to separate it all flavonoids in the form of glycosides or flavonoids in free form can dissolve in the form of methanol. The result to extract flavonoid compounds can be done by fractionation using several kinds of solvents with increased polarity 9 .

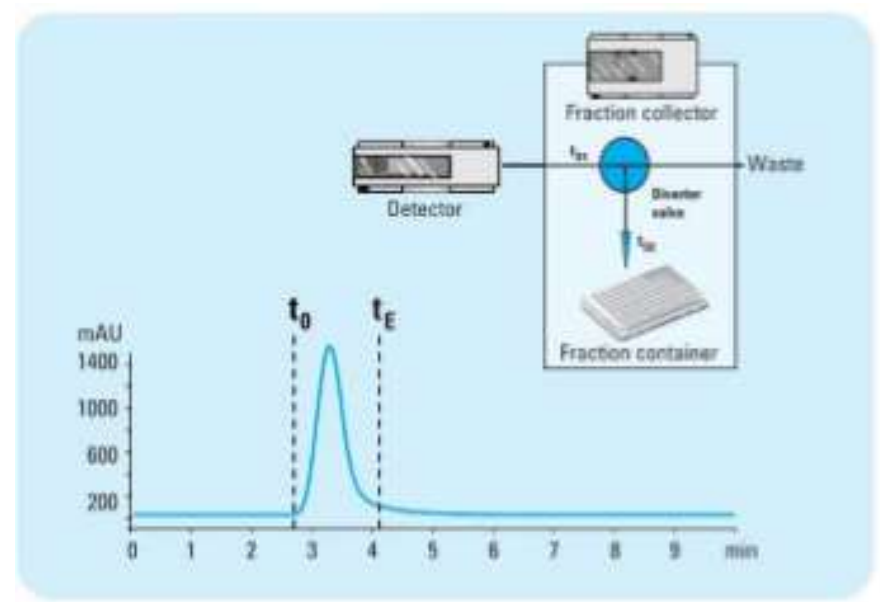

Fig. -1: Detection of Compounds by using HPLC ${ }^{8}$

The results using HPLC showed that Tetracera plants extracted leaves and stem parts showed that the wogonin content was found seen in Fig.-2(a). Based on research conducted contained wogonin type flavonoids by GC-MS method ${ }^{10}$.

The retention time of the wogonin reference standard was 18,334 minutes (Table-1) with the chromatogram shown in Fig.-2(b) the wogonin area in the Tetracera indica extract showed 69.20031 $\mathrm{mAu}$. Based on calculations using the formula contained in the method, wogonin levels are $12,3 \%$. In the Tetracera indica plant parts, the extracts detected in 18.184 minutes were seen in (Table-1) in the area $4688965 \mathrm{mAu}$.

Table -1: Levels of Retention Times, Tetracera indica Extract

\begin{tabular}{c|c|c|c}
\hline Source & Retention Time (minutes) & Area (mAu) & Area (\%) \\
\hline Wogonin & 18.334 & 690031 & 99823 \\
\hline Tetracera indica & 18.184 & 4688965 & 11.673 \\
\hline
\end{tabular}

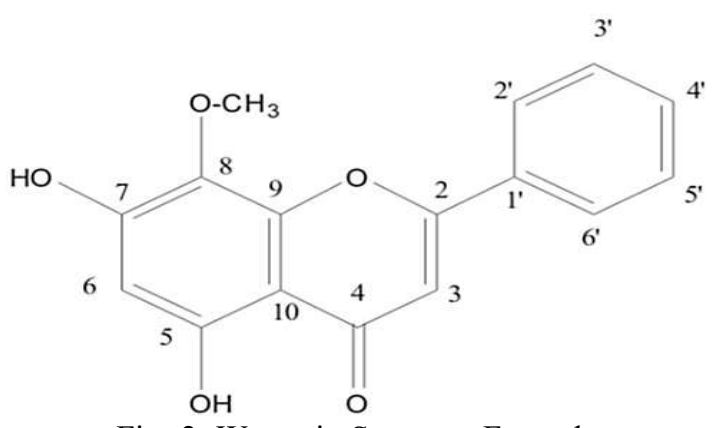

Fig.-2: Wogonin Structure Formula

The wogonin compound can be seen from the structure of the chemical formula in (Fig.-2) above. Wogonin is also an active component isolated from the Scutellaria baicalensis plant, one of the Chinese herbal medicines that are useful for the clinical treatment of inflammatory diseases including atopic dermatitis, hyperlipemia, and atherosclerosis ${ }^{11}$. Tetracera indica extract contains compounds of fatty acid groups, flavonoids and steroids according to belongs to the class of allelochemical compounds ${ }^{12}$. Tetracera indica plants in this study are only wogonin compounds because, although many compounds are identified including allelochemical groups, not every compound has allelopathic activity ${ }^{13}$. Therefore 
RASĀYAN J. Chem.

Vol. 13 | No. 2 |1124 - 1128| April - June | 2020 this study aims to determine the content of this wogonin compound that can be used as a bioherbicide in the pre-growth period with the type of weeds tested.

Chromatogram results obtained from the extract raw material and standards in this test are almost close to the same peak pattern. The spike injection technique on the wogonin reference standard and the Tetracera indica extraction results are a way to confirm whether the compounds in the extract are compounds that comply with the reference standard or not. The results of the spike injection show that some different peaks prove that the compound in the Tetracera indica extract is the same as the wogonin compound.

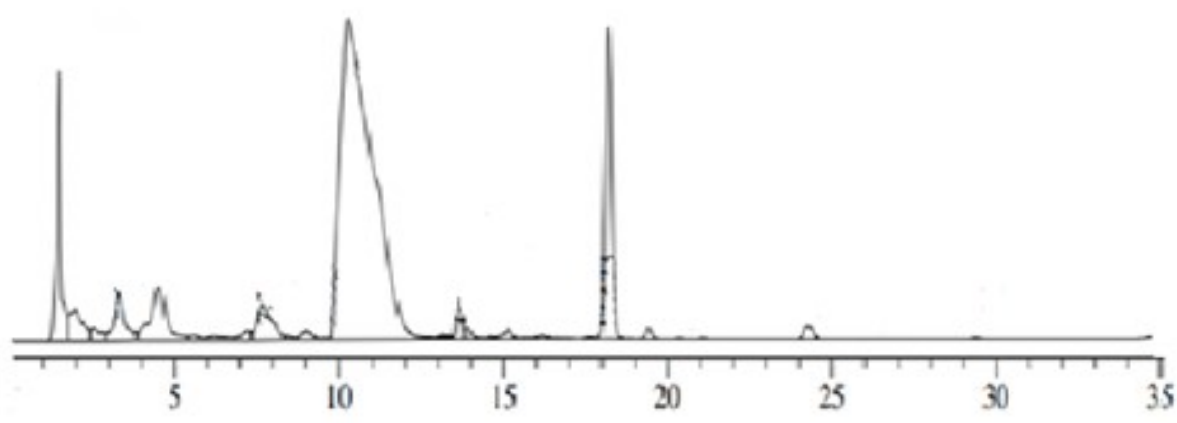

Retention time (minutes)

(a)

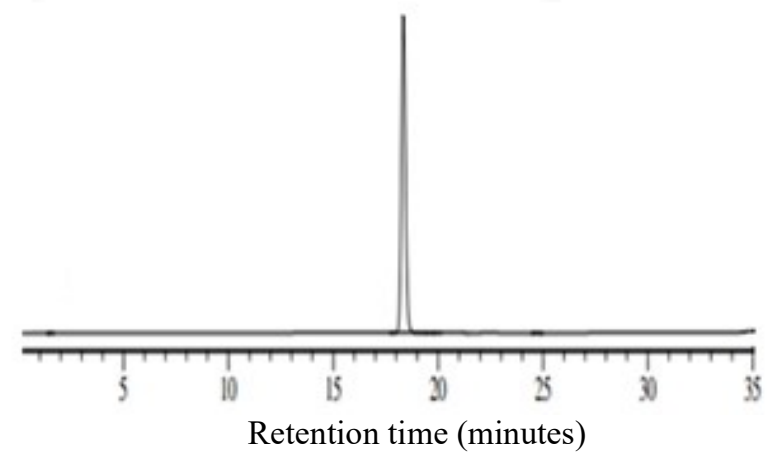

(b)

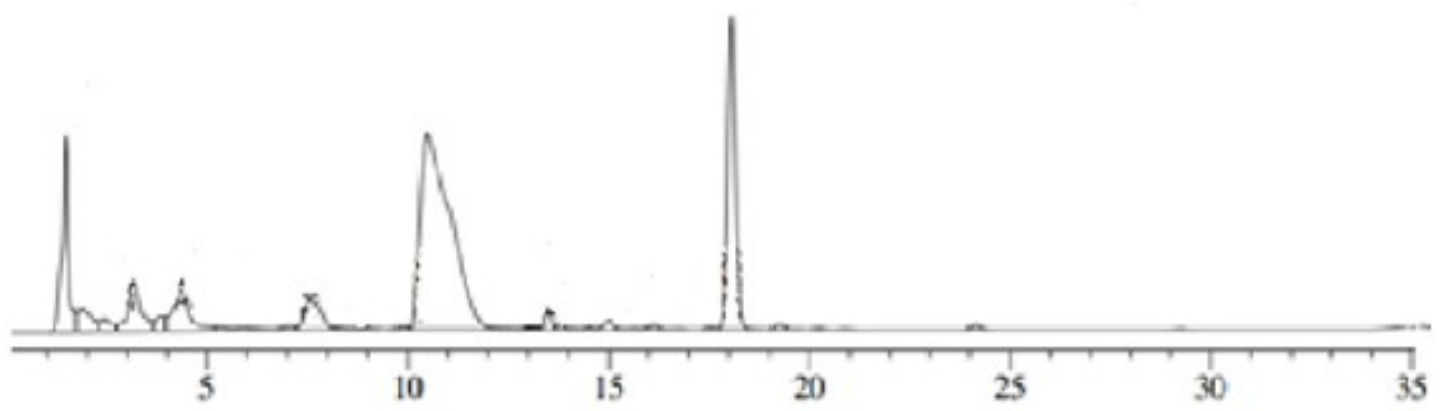

Retention time (minutes)

(c)

Fig- 3 HPLC Chromatogram of (a) Tetracera indica Extract; (b) Wogonin Standard (c) Standard Spike and Extract.

The results showed that in the Tetracera indica extract wogonin compounds were found with a retention time of 18,053 minutes in (Fig.-3c) The area of Tetracera and wogonin extracts was detected at 2729371 $\mathrm{mAu}$. 
RASĀYAN J. Chem. CONCLUSION

Vol. 13 | No. 2 |1124 - 1128| April - June | 2020

Wogonin compounds were found in the Tetracera indica plant extract at a retention time of 18,053 minutes from the reference standard and extract using spike injection at a wavelength of $254 \mathrm{~nm}$ by the HPLC instrument in this study.

\section{REFERENCES}

1. Fitrya, Muharni, Kobaywan, Jurnal Penelitian Sains, 15(3), 1(2012).

2. W. D. Rokhmaningsih, Potensi Ekstrak Tiap Bagian Tumbuhan Tetracera indica (L.) Merr. Sebagai Bioherbisida Pascatumbuh, Skripsi Fakultas Pertanian Institut Pertanian Bogor, Bogor, (2018).

3. D. V. Riskitavani, K. I. Purwani, Jurnal Sains dan Seni Pomits, 2(2), 59(2013)

4. Q. U. Ahmed, B. B. S. Dogarai1, M. Z. A. M. Amiroudine, M. Taher, J. Latip, A. Umar, B.Y. Muhammad, Journal of Medicinal Plants Research, 6(49), 5912(2012), DOI:10.5897/JMPR12.443

5. M. M. Hasan, Q. U. Ahmed, S. Z. M. Soad, J. Latip, M. Taher, T. M. F. Syafiq, M. N. Sarian, A. M. Alhassan, Z. A. Zakaria, Biomedic Central Complementary and Alternative Medicine, 17 (431), 1(2017), DOI: 10.1186/s12906-017-1929-3

6. H. Puspitasari, S. Listyawati, T. Widiyani, Biofarmasi. 1(2), 50(2003)

7. G. Jiayu, A. S. Medina, A. Barbara, Pendry, J. Michael, Hughes, P. Geoffrey, C. Olivia, Jounal of Pharmacy and Pharmaceutical Sciences, 11(1)(2008)

8. U. Huber, and R. E. Majors, Introduction into Preparative HPLC, Principles in preparative HPLC, 2(10),(2007)

9. J. B. Harborne, Metode Fitokimia Penuntun Cara Modern Menganalisa Tumbuhan, Bandung (1987).

10. Fitrya, L. Anwar, F. Sari, Jurnal. Penelitian Sains, 12(3), 1(2009)

11. Ying-ling, Chang, J. Jong, Shen, S. Being, Wung, J. Jing, Cheng, and D. L. Wang, Molecular Pharmacology, 60(3) (2001), DOI:10.1002/cpt.592

12. R. Saxena, R. S. Tomar, M. Kumar, International Journal of Current Research in Biosciences and Plant Biology, 3(4), 43(2016), DOI:10.20546/ijcrbp.2016.304.008

13. E. L. Rice, Allelopathy, New York, (1984).

[RJC-5522/2019] 